\title{
A Crisis-Driven Migration? Aspirations and Experiences of the Post-2008 South European Migrants in London
}

\begin{abstract}
Since the 1990s young South Europeans have been attracted to London by the dynamic labour market and cultural radiance of the city, but also pushed by unfavourable conditions in the labour markets of their origin countries. Subsequently, the Eurozone crisis, austerity politics and their socio-political consequences have markedly intensified migration rates. But did they also signify a rupture in terms of the motivations, experiences and aspirations of the migrants? Drawing on indepth interviews with Greek, Italian and Spanish migrants of different educational levels, we find that post-materialist motivations and pro-migration dispositions prevail among the "crisismigrants". Migration is seen and experienced as a step forward, rather than a disruptive force, signalling a positive message in defence of intra-EU free mobility. Yet at times of neoliberal deregulation and economic and political uncertainty, aspirations for socio-economic stability and settlement are also of growing importance, questioning mobility as the normative way of contemporary life.
\end{abstract}

Keywords: Eurostars, Eurozone crisis, Liquid migration, London, Migration Decision Making, Southern Europe

\section{INTRODUCTION}

Since the 1990s London became the target of young South Europeans who, along with other continental Europeans, have been arriving in the city for work, study, career advancement and lifestyle reasons. They were attracted by the dynamic labour market and cultural vibrancy of a metropolis that was emerging as the prime destination of European free movement. In his landmark book Eurostars and Eurocities, Adrian Favell (2008) provides a thorough account on the reasons 
that underlay the mobility decisions of those predominantly young and highly educated "highflyers".

The 'Eurostars', the protagonists of Favell's ethnography, move between key European cities such as London, Amsterdam and Brussels seeking and practising a denationalized freedom in both the spatial and cultural sense. Unrestricted mobility in the European space gifts them the ability to seize work and life opportunities abroad but also to play with ascriptive national identities that hitherto might have felt fixed and stamped for life. Their mobilities are thus informed by a wish to liberate themselves from what they see as a limiting life within the bounds of restrictive national cultures and to escape from career frustrations at home.

Career frustrations play a particularly significant role in the migration decision-making of the South European Eurostars whom Favell portrays as prototypical rational free-movers pushed by unfavourable conditions in the labour markets of their home countries:

Growing up in countries where advancement is seen to be blocked by hierarchical, nepotistic, or arbitrary career paths, they pursued an alternative route abroad. The decisions were individualistic, clearly calculated, and articulated in these terms. Issues to do with family, friends, or their preference for the Southern way of life were discounted against the benefits of a career move to a dynamic Northern city, particularly in terms of human capital enhancement. The decision is recounted in these terms, and the calculation is still ongoing. Most of them reckon on cashing in their move some day and going home (Favell, 2008: 63).

Yet what is presented by Favell's interviewees as a logical, almost self-evident decision was, until recently, only taken up by a small minority of South Europeans. Before the 2004 and 2007 enlargements, migration within the EU was quite limited (Recchi, 2015) and South Europeans notably featured as the European citizens least disposed towards long-distance mobility (European Commission, 2010). However, the combined effects of recession, extreme austerity, and their socio-political consequences transformed mobility intentions and forced many to actually take that step. The Eurozone crisis brought a sudden aggravation of those conditions that were already acting as push factors, triggering a steep increase in emigration rates. But did they also signify a rupture in terms of migrants' motivations, experiences and aspirations? How do post-2008 South 
European migrants assess their migration to London, a global metropolis that has been attracting migrants from the European South already before the crisis?

Challenging the tendency toward a "sedentarist analytical bias" in a wide spectrum of sociological fields of enquiry, the mobilities paradigm has problematized linear understandings of migration as a one-off event involving a relocation from A to B (Cresswell, 2006; Urry, 2001). Along the same lines, transnationalism describes migration as a lifelong process of complex interactions between the countries of origin and settlement and beyond (Levitt and Glick Schiller, 2006). Both approaches highlight the complexity of migration trajectories which may include a variety of mobility practices including onward and return migrations, circulation between places and short-term mobility. Such realities may be sustained by attitudes of intentional unpredictability and an open-minded stance towards mobility or even by a positive embracement of the lifestyles of mobility. Sustained mobilities, however, may also be coping strategies for structural disadvantage, or compromising responses to demands for enhanced flexibility and spatial mobility by welfare-competition states and neoliberal global regimes (Faist, 2013). Such demands are not only making the contemporary world more "liquid" and mobile (Bauman, 2005), but also rendering nomadism the "appropriate attitude" and transnationality an important resource for the successful navigation of social life.

Kaufmann et al. (2004) propose the term "mobility capital" to describe people's capacities in relation to the surrounding physical, social and political possibilities for movement. These are unevenly distributed across class, gender, ethnicity and age lines and are determined by the legal structures regulating who or what can and cannot move. Legally unconstrained migration in the EU makes for a unique mobility system that provides European citizens with increased mobility capabilities and has contributed to the overall positive assessment of mobility projects as described by Favell (2008), Recchi (2015) and others. However, the earlier optimism about the European project, and its associated principle of freedom of movement, has been waning over recent years. Free mobility is increasingly being questioned in political and public debates in Western European countries, nowhere more so than in Brexit-era Britain, and is negatively related to discussions about ongoing brain-drain in Southern Europe. How are the migration projects of the crisis-driven South Europeans contextualized in terms of the current power dynamics that exist between the different localities across which they migrate and in the context of the Eurozone crisis that has led to the de facto re-emergence of "core-periphery" relations within the EU (King, 2015)? Do they 
still see their emigration as a step forward, a sign of personal development and an opportunity to advance one's life; or as a disruptive force, a necessary evil to survive in a period of neoliberal deregulation and economic uncertainty in which flexibility and socio-spatial mobility are praised and valued and migration paradoxically resisted? This paper sets out to answer these questions with reference to Greek, Spanish and Italian migrants in London. It further aims to explore narrative similarities and differences between the three groups.

Data were drawn from in-depth semi-structured interviews, carried out with purposively drawn quota-samples of young adults who were aged between 18 and 39 at the time of migration to the United Kingdom, and aged up to 42 at the time of interview. In total we conducted 44 indepth interviews approximately equally split between men and women, across the three national groups, and between higher and lower educated workers. The average interview time was 1 hour and all interviews were conducted in migrants' native language, recorded, and transcribed directly into English to enable cross-group comparative analysis. Interviewees were accessed via a variety of contact methods-personal networks of the authors, community organizations, and snowballing. The main themes of the interview were reasons for migration, experiences of work and life in the United Kingdom, and plans for the future. Interviews were conducted between September 2015 and May 2016, i.e. during the months preceding the 23 June 2016 referendum on the UK's continued membership of the European Union.

\section{THEORIZING LEGALLY UNCONSTRAINED MIGRATION IN THE EU}

Recchi (2015: 81) has rightly pointed out that, as a sociological category, mobile European citizens have been relatively little studied within the broad universe of migrants; while there is considerable conceptual work on European free movement as an institution, there is much less theorizing on how intra-EU mobility is practised.

In his aspiration/ability model, Carling (2002) analytically distinguishes between the migration as a potential course of action and the realization of actual mobility. He highlights that when people develop a wish to leave, the outcome depends on their capacity to convert this desire into reality depending on context-specific barriers and constraints which each potential migrant is differently equipped to overcome. He further argues that the most significant barriers to migration are often restrictive immigration policies. The process of European integration has constructed a 
supranational area within the borders of which the power of nation-states to control individuals' choices of travel and settlement has been curbed (Recchi 2015: 145). Free movement within the EU thus makes migration an easier mobility strategy to pursue, reducing its economic and psychological costs, and accounts for a radically different context within which to assess how migration decisions are taken and practised.

The concept of "liquid migration" has been put forward as one way of conceptualizing the migration of European citizens in the context of free mobility. First coined by Engbersen et al. (2010), inspired by Bauman's $(2000 ; 2005)$ work on liquid modernity and liquid life, liquid migration is characterized by six key elements: 1) temporariness of flows with patterns of circular and ongoing migration prevailing, 2) primacy of economic motivations, 3) legal residential status among the migrants, 4) spontaneity in migration decisions and unpredictability of migration flows, 5) individualized patterns of migration, and 6) a "migrant habitus" characterized by a deliberate stance of keeping options open (Engbersen, 2012). Those characteristics were specified with reference to post-accession East-West migration, which is one particular case of intra-EU mobility. As such they are too narrow to account for the migration of European citizens in general.

Eastern Europeans were faced with blocked mobility in the pre-1990s era and had very limited opportunities for legal migration in the period that immediately followed the fall of the Iron Curtain. Legally unconstrained mobility after the lifting of the restrictions and high wage gaps triggered patterns of circular or temporary labour migration to West European destinations. Yet the primacy of economic motivations cannot be said to be a defining characteristic of intra-EU mobility in general; quite the contrary. Several studies have highlighted the significance of nonmaterial considerations for EU citizens who move looking for healthier environments, selffulfillment, new lifestyles, better socio-political systems, a better quality of life, as well as because of love (Favell, 2008; King, 2002; Santacreu et al., 2009). Similarly, temporary, circular and seasonal patterns of migration are not unique to intra-EU mobility as they have occurred in many spatio-temporal contexts in the past (King, 2018).

Despite such caveats, several scholars have endorsed (with some reservations) the concept of liquid migration as a useful metaphor for describing the context of contemporary intra-European mobility (Bygnes and Erdal, 2017; King, 2018; Lulle et al., 2018). They focus on the fluidity of migration decisions and trajectories enabled by the free movement regime. They also highlight the individualization of migration decisions, which requires further qualification. 
Focusing on Greeks emigrating in the years of the Eurozone crisis, Pratsinakis (2019a) argues that, contrary to what is proposed by the New Economics of Migration theory (Stark and Bloom, 2015) and indeed in line with the individualization thesis, migration is neither the outcome of collective decision-making by extended families nor part of a family plan that implies that some members of the household stay in the place of origin and others migrate abroad. The share of Greek migrants who leave members of the nuclear family back in Greece is very low, as is the flow of remittances. Yet the data presented in Pratsinakis' study also indicate that, contrary to pre-crisis emigrants, who saw their emigration as a career move followed by an eventual return to Greece, most of the post-2010 emigrants leave Greece due to a depressing lack of prospects in their home country. They plan a longer stay abroad driven by a search for more predictable and stable lives. This is especially the case for those who leave Greece for reasons relating to the future wellbeing of their offspring as well as for couples who emigrate together to be able to lead an independent life. Emigration is not planned by extended families, but family considerations play an important role in the decision-making of several migrants.

Motivations to live abroad for reasons of self-exploration, personal freedom as well as lifestyles of mobility are still relevant, especially among young single Greek migrants (Pratsinakis, 2019a). However, as Bygnes and Erdal (2017) have also illustrated with reference to Polish and Spanish migration to Norway, a desire to ensure a grounded and secure life for oneself and one's family is becoming increasingly important. For the Polish migrants, this possibly points to the dynamics of the migration process which, as Friberg (2012) has described, often develops through a series of stages, starting with circular migration but then maturing towards settlement and community formation. For the Spanish migrants in Bygnes and Erdal's study, as well as the Greek migrants in Pratsinakis' study, it may signal a transition to longer-term settlement caused by the prolonged crisis in both countries.

This raises questions about the ways South Europeans assess and frame their migration to London at times of crisis as well as the differences that may exist between age, employment and educational categories and the three national groups interviewed. As will be shown in the next section, all three countries were substantially impacted by the Eurozone crisis but significant differences can be also observed.

POST-2008 SOUTH TO NORTH MIGRATIONS IN THE EU 
In the last decade, a renewed public discussion on emigration has taken place in Southern Europe. In this discussion, worsening socio-economic conditions are cited as push factors contributing to what is seen as a new major population outflow affecting notably the young and highly skilled. However, this diagnosis is often based on anecdotal information, which tends to exaggerate the actual volume of emigration.

Data from Eurostat do show a considerable increase in emigration rates in the years following the Eurozone crisis. Annual outflows of nationals in 2016 are more than double those of 2008 for Italy and almost triple for Spain and Greece. However, when looking at annual outflows as a share of the general population, emigration of Spanish and Italian citizens is still rather limited (Figure 1) and below the EU mean. ${ }^{1}$ Emigration has become significant only among the Greeks who after 2011 exhibit one of the highest emigration rates in the EU28 (after Romania, the Baltic States and Ireland).

\section{Figure 1}

Despite differences in the relative volume of emigration, available data indicate that a common characteristic in all three countries is the relatively high number of university graduates (Conti, 2012; Diaz-Hernandez and Parreno-Castellano, 2017; Labriandis and Pratsinakis, 2016). Apart from the self-selectivity of migration, by which the highly skilled are among those most likely to move and most capable of doing so, local labour market conditions seem to be particularly unfavourable for the highly skilled, thus explaining their over-representation among the emigrants. Eurostat data show that, of the EU28, Greece (48\%), Italy (52\%) and Spain (69\%) have the three lowest employment rates for young highly skilled people, in the first two cases well below the EU average (82\%). In these Southern EU countries, especially in Greece and Italy, education does not provide strong advantages in terms of access to work, which is in contrast not only with the situation in West European countries but also in those of Eastern Europe, partly accounting for the difference in the educational backgrounds of East and South European mobile citizens (the former being more often lower skilled and the latter highly skilled).

The explanation for graduates' low employment rates in Southern EU countries lies not in the supply side (as the share of people with university education is around the EU mean for Greece 
and Spain and is the second lowest in the EU for Italy), but rather in the demand side of a labour market failing to absorb this educated workforce (Labrianidis and Pratsinakis, 2017). To that we should also add the features of nepotism, gerontocracy and informality of employment arrangements in these countries, all of which make up for labour markets that are inaccessible to the highly educated in Greece and Italy and, in the shadow of the crisis, increasingly so in Spain too.

The combined effect of the emigration of a highly educated labour force on the one hand and recession and austerity on the other has triggered heated and politicized debates in all three countries. In Greece both left-leaning and popular right-wing press have been assigning responsibility to the choices of the governments which implemented austerity politics, often described as treasonous, and suggest a coordinated attempt of Northern European governments to draw the best talent from the South through the imposition of punitive and counterproductive fiscal measures in Greece (Mavrodi and Moutselos, 2017). In Spain the issue has been taken up by opposition parties blaming the conservative right-wing party for lack of opportunities for the highly skilled in the Spanish labour market (Bermudez and Brey, 2017). Left-wing parties further describe the new emigration as an economic exile caused by recession and austerity politics; a discourse that has also been taken up many several organizations and initiatives of Spanish migrants abroad (Bermudez and Brey, 2017; Sala, 2017). The Spanish migrants, have been very vocal in problematizing their migration as forced by the circumstances back home and accusing the governments for their denial of the phenomenon (Sala, 2017).

In Italy discussions about the brain drain predate the crisis and policy attempts to reach out towards the diaspora of professionals were already in place, though with insignificant effects (Tintori and Romei, 2017). Unlike Spain and Greece, whose economies were growing in the years preceding the Eurozone crisis, the Italian economy has been suffering from sluggish or zero growth already since the 1990s (Tiffin, 2013). The series of recessions that followed the Eurozone crisis aggravated the situation; however, the consequences were not as acute as in Spain and especially Greece whose economy suffered an unprecedented contraction in GDP of more than a quarter between 2008 and 2014 (Figure 2). For sure, unemployment rates did increase in Italy (12.7\% in 2014 compared to $6.7 \%$ in 2008), but they never reached the dramatic proportions they acquired in Greece and Spain where in the 2012-14 period they skyrocketed to more than 25\% for the general population and more than $50 \%$ for the youngest economically active age cohort (Figure 
2). Thus, brain drain appears to be a more longstanding issue in Italy, whereas in Spain and Greece it only reached critical proportions in the post-2008 period, even if its structural preconditions predated the crisis.

\section{Figure 2}

However, despite its significance, the exclusive focus in political and public debates on the emigration of graduates has led to a misleading equation of the new crisis-driven emigration from Southern Europe with the phenomenon of brain drain. As a result, the term is often applied indiscriminately to all people leaving regardless of their qualification and occupation, while the emigration of older people and the less well educated is neglected (Bermudez and Brey, 2017; Pratsinakis et al., 2017; Tintori and Romei, 2017). The deterioration in the quality of life, loss of employment and impoverishment brought about by recession and austerity in all three countries not only intensified emigration flows among the highly skilled but altered mobility aspirations and decisions more widely. The crisis has thus pushed out of those countries people of lower socioeconomic backgrounds whose experiences are less well documented. Aiming to account for this lack of attention, in our paper we address and comparatively assess the experiences and aspirations of both high- and low-educated migrants.

It should be further noted that there are significant differences in terms of the educational background of the emigrants by destination country. More poorly educated people migrate to the traditional destinations of postwar emigration because they can make use of social networks available to them to secure employment in ethnic niches in those countries, while highly educated emigrants find jobs mostly through applications for (publicly advertised) vacancies based on their own attainments. Consequently, Germany, the most favoured destination together with Britain, attracts a majority of people with low to medium levels of education, while those who migrate to Britain are more often people with high educational qualifications (D'Angelo and Kofman, 2017; Klekowski von Koppenfels and Höhne, 2017).

GREEKS, ITALIANS AND SPANIARDS IN THE UK 
The UK has emerged as a very dynamic destination for the new South European migration. As seen in Figure 3, the Greek and Spanish population more than doubled within a time span of only six years (2011-17) and the Italian population rose by $84 \%$. According to data from the national insurance number (NINo) registrations, the decision of the UK to leave the EU seems to have significantly slowed the inflow of Italians and Spaniards, but not the Greeks. NINo data further indicate that recent arrivals gravitate primarily in Greater London and the South East which account for approximately $60 \%$ of the total UK population of those three nationalities. Male migrants seem to be slightly over-represented for all three nationalities (more so among the Italians, 59\%) and the vast majority of the migrants (more than $70 \%$ for all three groups) fall in the 18-24 and 25-34 age bands, with the Greek migrants being more over-represented in the latter. Older migrants are a minority but their share is increasing in the past few years as the crisis seems to have pushed several people to take the emigration option at a later phase in their life-course.

\section{Figure 3}

Greek, Italian and Spanish migrants in the UK form a very positively selected group with a high share of university graduates. Data from the Labour Force Survey in the second quarter of 2017 show that $72 \%$ of Spaniards, $67 \%$ of Greeks, and 53\% of Italians have tertiary education. The same source shows that the clear majority of them work in professional and associate professional jobs, and approximately one-quarter work in various jobs in the service economy. In the years before the crisis there was a significant outflow of young Italians and Spaniards moving to the UK to explore life abroad and learn English, whereas Greek emigration was more an elite migration informed by career advancement considerations. However, migration motivations diversified for all three nationalities in the wake of the crisis.

\section{MIGRATING TO LONDON FORCED BY THE EUROZONE CRISIS: THE NECESSITY- DRIVEN MIGRANTS}

Lack of a job and/or marginal socio-economic conditions shaped the migration to London of several research participants. Many of those migrants highlighted the centrality of the crisis in shaping their rather abrupt migration decisions. Giorgia $(31, \mathrm{GR})$ revealed that a year before she 
left Greece, emigration had not crossed her mind. She had invested the savings of several years' work in the hospitality sector to open, together with a friend, a tapas bar in the centre of Athens. Their business had gone through difficult times, but they had managed to keep it going and gradually things started looking up. But the imposition of capital controls, which were put into effect in 2015 in Greece, was a huge blow.

People stopped going out. I mean, things became very bad after the capital controls were imposed... everything ended. Four months of slack can be coped with; but not more [...]. And so, I was thinking what I should do, it's only once in my life I'm 30 years old. I thought I shouldn't fight for my business anymore... It was worthless. I couldn't describe a more depressing situation... [...] I wanted to fight for my future; you can't do that in Greece though... You fight a battle you can't win there... I mean, it's depressing...

Giorgia sold her car to support her migration project and left Greece. She was initially hosted by friends in London until she found a job and moved out. She started working as a waitress. Professionally her migration entailed a downward move. Her housing conditions were also worse than in Greece. Like the majority of the interviewees, she was living in a room in a shared apartment. Yet she was happy with her decision to move to London and was planning her future there, not considering returning to Greece any time soon.

Giorgia explained that in Greece she felt trapped in a situation in which she was unable to plan her life. She was devastated by the fear she described as being gradually instilled among people in Greece -a fear that paralyzes and makes them downscale their expectations. She told us she was not willing to cope with this situation. Her life in London came with many hardships and a lot of stress, but also excitement about new experiences, expectations about the future and a firm belief that she can gradually progress and build her life there. Her goal was to open her own business in the tourism sector.

Difficulties, but also continuous progress, likewise characterize the story of Giulia (IT, 33) who migrated to London after she got fired by the company where she had been working for eight years as a book-keeper. Giulia started off working as a cleaner before she found a rather badlypaid part-time office job. This was followed by several temporary but better-paid jobs until she gradually managed to secure a full-time and more stable position as logistics administrator. Giulia 
had not accomplished her goals professionally at the time of the interview, but she felt her trajectory in London compares very favourably to what she thought her future in Italy would be. In her own words:

My prospects [in Italy] were very sad before I migrated because I was nearly 30 and the government didn't give tax breaks for people over 26. There wasn't any job, the salaries had gone down a lot, my only prospect was to stay in Italy and be dependent on my parents. With or without a job.

Giorgia and Giulia, along with other migrants whose move was forced by circumstances induced by the crisis, can be described as necessity-driven migrants. Those migrants had a lesser ability to plan their move strategically. That was especially the case among the Greeks who had a strong need to escape their crisis-ridden country and were hence eager to hasten their emigration projects (cf. Pratsinakis et al., 2017). Motivations relating to personal development and adventure were less strong in shaping their migration decision-making, but a favourable attitude towards mobility was prevalent and migration was seen as a great learning experience. Most of the necessity-driven interviewees had not secured employment prior to migration and moved to London to look for work opportunities "on spec". Finding employment proved to be easy and many claimed that "if you want to work in London you can easily find a job". Finding a job matching their qualifications and working experience prior to migration, however, was more difficult. Yet most of them expressed a belief they can make it in the long run and embraced a strong work ethos with that target in mind.

Most of the necessity-driven migrants left their country at a later phase in their life-course, often 30 or older. Salvador (SP, 42) and Apostolos (GR, 41) both emigrated at the age of 39 after their businesses (a restaurant and a small-scale sales company) went bankrupt. Apostolos and his wife, Tina, left Greece when Tina was pregnant. Contrary to Giulia and Giorgia who favoured London's lifestyle and planned to stay there, Apostolos, who migrated first, found London too expensive and not suitable for a family life. He moved to Brighton where he was joined by Tina. At the time of the interview they were considering moving further out into the countryside to be able to afford a larger apartment but also to find a space where Apostolos could start his own business in retail after two years working as a waiter in a Greek restaurant. 
Migration was described by the necessity-driven migrants as means to progress and a way to restore the socio-economic stability which they had lost over the past years in their countries of origin. Further migration was not among their plans. Similar to the Polish and Spanish migrants interviewed by Bygnes and Erdal (2017) in Norway, they were seeking to create the grounded and predictable lives and futures that were no longer attainable in Southern Europe. Speaking English was a key reason that brought them to the UK, together with positive expectations about the availability of jobs as well as the presence of friends in London. Plans for longer-term settlement in London differed among the research participants, depending on individual and family characteristics. Some were treating their stay in the city as the first step for settling elsewhere in the UK; others planned to remain in London for the foreseeable future.

Even if most of the necessity-driven migrant interviewees were people without university degrees, we do encounter Greek highly educated migrants in this category, but no Spanish and Italian interviewees. Greeks were generally over-represented among the necessity-driven migrants and in contrast to the other nationalities they planned a longer settlement in the UK, having completely lost faith in their ability to build a predictable future under the volatile economic environment of crisis-ridden Greece. However, and contrary to what one may have expected, the necessity-driven migrants were a minority among the overall sample interviewees, including the Greeks.

\section{MIGRATING TO LONDON AS A PLANNED CAREER STEP: THE CAREER-ORIENTED MIGRANTS}

Another minority group among the research participants are the career-oriented migrants. They are akin to the "global nomads", a category coined by Jordan and Düvell (2003) to describe the highly mobile professionals who move from one country to another depending on work opportunities that arise as a result of the integration and globalization of the world economy, and who often exhibit a cosmopolitan orientation (see also Düvell and Vogel, 2006). The careeroriented interviewees were exclusively highly educated, mostly in IT, business and economics, and treated their move as a means to embark on or further advance their professional career. They contrasted with the necessity-driven migrants in that their migration was very marginally, if at all, influenced by the economic crisis in their countries. 
Migration was described by them as a strategically identified step in a planned career path. Working in a global metropolis was seen as a critically important experience for their professional trajectories, irrespective of the structural deficiencies in the labour markets in their countries and the worsening of the situation brought about by the crisis. For them social networks were not important in accessing employment in London, as was often the case with the necessity-driven migrants. They commonly found employment through applications for advertised vacancies before emigrating, or were headhunted or transferred by an employer. London was presented as a more or less self-evident destination within Europe for the size and dynamism of its labour market and the opportunities it provides to young and upcoming professionals. In many ways their migration can be seen as part of a long stream of career migrations to London that is not characteristic to the European South but rather global in its origins (eg Beaverstock and Hall 2012; Favell 2006). London's privileged position as a global financial centre with a transnational reach and a cosmopolitan appeal has been pivotal in attracting "career-oriented migrants" and placing London in a top position in the global talent competition.

Career-oriented migrants were open-minded about their future, and in some cases planned onward migration to faraway places such as Silicon Valley, New York and Tokyo as the next steps in their professional path. As Ernesto (IT, 28), an IT developer, said: “... being too static. I don't get it. Like, I'm here now but I'm already thinking about where to go in a couple of years, because I don't see this as a point of arrival but as a step". The same attitude was endorsed by Laura (SP 22) and Yorgos (GR 33), both working in the banking sector, who considered a move to another big cosmopolitan city a very probable scenario for the next five years.

Most career-oriented migrants were younger in age, which helped them sustain a lifestyle of mobility. However, they planned to settle at a later phase in their life-course, primarily for reasons of family formation. Ernesto, who was single at the time of the interview, expressed a general wish and expectation to eventually return to Italy, but not within the next 10 years. The Greek career migrants were again more disillusioned about the potential of having a stable and satisfying professional life in Greece, and were hence less oriented towards a return. They could foresee settling in London in the longer run while leaving other options open, as was characteristic of people in this category more broadly. 


\section{MIGRATING TO LONDON AS A WAY OF GETTING AHEAD IN LIFE: EUROSTARS AND “MIDDLING TRANSNATIONALS” IN TIMES OF CRISIS}

If we conceptualize the influence that the Eurozone crisis has had on the emigration decisions of South Europeans as lying along a continuum with the necessity-driven migrants and the careeroriented migrants forming the two polar opposites, the majority of our research participants would fall somewhere in between. The interviewees of this majority category expressed a pro-migration attitude, and many of them noted that they had always wanted to leave their countries and live abroad. The economic crisis in Southern Europe has not had a direct impact in shaping their decision to emigrate, unlike the necessity-driven migrants. Yet, unlike the career-oriented migrants, the crisis was often important in reshaping the wider socio-economic dynamics that triggered their decision to leave.

A common denominator among the research participants of this diverse category is that they treated their migration project as a way to get ahead in life. Younger participants were overrepresented in this category: they wanted to "use" migration as a route towards leading an independent life without being dependent on family support and the life-stage stagnation that this entails. Most of them had jobs in their countries of origin, so that migration was not shaped by an urgency to get employed as in the case of the necessity-driven migrants. Yet certain events, often related to the eurozone crisis and the imposition of austerity politics in their countries, such as the worsening of working and employment conditions, the gradual aggravation of the socio-political environment or the emigration of their partner or a close friend, played an important role in their decision-making. The majority had the ability to plan their emigration more smoothly than the necessity-driven migrants and many, especially the highly educated, had secured employment in London before emigration. They migrated aiming to achieve a sense of personal fulfilment and progress coupled with socio-economic stability. To attain this goal, they looked for employment opportunities in London that would advance their career, but equally importantly, which would also offer better working conditions.

Several of them embarked on an attempt to pursue their dream career by seeking employment in a creative field they had long given up trying in their countries of origin. For instance, Paolo (IT, 31), who had studied linguistics but was also into writing music, migrated with the aim of pursuing professionally his passion for electronic music. Fabiola (IT, 30), who had 
studied political economy, moved to London so that she could combine work in this field with acting. Other interviewees migrated to be able to find work in their fields of study which had proven to be impossible in their countries of origin. This was the case for Innes (SP, 31) who had studied media production and wanted to work in the film industry in London. She had managed to get some small assignments, but she had not yet achieved her goal at the time of the interview. She was working meantime as a fitness instructor.

I need to make efforts, not to give up, and especially I know I need experience, I need to get experience here but it's something that I can't achieve by myself, is not in my hands, the only thing I can do is to continue making efforts without giving up, that's in my hands [...]. The problem with film is that when you are coming from abroad without any experience here, that's difficult [...] for here people are considered younger at an earlier age. In the rest of Europe when you are 30 you are still young but not here, here you have more possibilities if you are under 21 , or maybe $25 \ldots$

Many interviewees, especially those who emigrated later in their life-course, compared themselves to non-migrants and expressed feelings of lagging behind in terms of their school-to-work transitions. For instance, Panos (GR, 36), an electrical engineer, noted:

Here they have very quick career development. Their studies are shorter, there is also availability of work so when they are 23 they can already start in their professional lowest rank, the one I also started at when I came here. Then they move up - intermediate, senior managers... We, the newcomers who entered the market late, have to act fast and smartly to move up.

Those interviewees who did not foresee a swift return to their country, primarily Greeks but also several Spaniards with qualifications in fields where there was reduced demand, were strategic in quickly advancing their careers by changing jobs and combining work and study. The Greeks got very frustrated if they had to work in jobs unrelated to their field of education and work experience. Migration motivations relating to self-exploration and a wish to experience the vibrant social and cultural life in a global city were important for all migrants in this category. But they 
weighed more in the decision-making of the highly skilled Italians and secondarily the Spanish high-skilled migrants. Learning English was an important migration motivation for many Spanish and Italian migrants but not for the Greeks who generally had better English on arrival, often supported by private lessons they had taken prior to migration. The former saw their migration as an opportunity to develop skills which could be capitalized on their return to Spain and Italy, while the Greeks saw their language skills as a tool that could help them succeed in London.

For the graduates in social sciences and humanities, finding employment that matched their qualifications and subject specialisms was not easy and many had to take up jobs in the service economy, sharing similar employment trajectories with lower-educated migrants. The trajectories of those with education in hard science, engineering, business, medicine and IT were much more favourable, resulting in faster upward career mobility. Their pathways resembled those of Favell's (2008) Eurostars, whilst the rest of the interviewees in this category would be more appropriately described as Conradson and Latham's (2005) “middling transnationals" with middle-range office and administrative work or employment in the education or health sector.

\section{CONCLUSION}

The Eurozone financial crisis has had a spatially uneven impact, such that it has "reperipheralized" Southern Europe as a broad region of economic fragility and of resurgent SouthNorth migration (King, 2015), with London emerging as a prime destination for these new mobilities. As one would expect from economic logic, outflows of migrants are broadly correlated with high unemployment rates, and inversely related to average disposable incomes in South European countries. However, it would be to commit an "ecological fallacy" to confound macroeconomic migration determinants with individual motivations - as the "push-pull" model of migration tends to do. Any macro-level model should be underpinned by a credible microbehavioural link that takes into account people's agency, aspirations, relationships to others (family members, partners, friendships groups etc.), and their resources to materialize their aspirations and ambitions (Carling, 2002; Pratsinakis, 2019b). The existence of legally unconstrained migration in the EU makes for a unique mobility system and creates a laboratory for studying how migration may develop, and be experienced and assessed, in a post-national space at times of economic crisis. 
Our data show that unemployment and/or marginal conditions are indeed pushing younger people out of Southern Europe who emigrate to restore the socio-economic stability which they had lost (or never achieved in the first place) over the past decade in their countries of origin. However, there is another group of respondents, more numerous in our sample, who have left Southern Europe not out of the direct desperation of unemployment or a failed business, but more as the enactment of a general strategy to "get ahead in life" and avoid social stagnation (cf. Pratsinakis, 2019b). The narratives of these participants are in accordance with the findings of Bartolini et al. (2017) who highlight the importance of post-materialist motivations of recent Southern European migrants, even those who left in the crisis era.

At the same time, whilst individualized lifestyles of mobility, and motivations driven by the vibrant social and cultural life of London are persistent features of South European migration to London, their centrality has lessened over the years of the crisis. Mobility is not embraced, to the extent that it was before, as a continuous lifestyle, and neither is it romanticized by the majority of our informants. Similarly, career-driven migration is not a dominant mobility mode, effectively concerning a minority of movers working in the banking sector or in other dynamic areas of the economy.

Overall, the emigration of South Europeans to London seems to be going through a transition within which a desire for more "grounded lives" is becoming more prominent (cf. Bygnes and Erdal, 2017), even though settling down in London is challenging due to high living costs and the size and complexity of this metropolis, making future plans ambivalent. Despite this ambivalence, free intra-EU mobility and the opportunities this opens up were praised by our participants, who use their increased mobility capital to avoid social stagnation in the face of the economic crisis and structural deficiencies in the labour markets in their countries of origin. They also viewed migration to London as a valuable learning experience and a means of self-exploration and personal development. Yet that did not go hand-in-hand with an embrace of continuous spatial mobility as the normative way of contemporary life. Excluding a minority of informants who had the financial capital to support such lifestyles or were working in industries that facilitate or require frequent relocation, migration to London was seen as a step to finding a more fulfilling job and establishing a more secure life. Thus, their narratives and aspirations on the one hand signal a positive message in defence of intra-EU free mobility at a time when it is under attack from neonationalist politics and the normalization of sedentaristic residential allegiences, while on the other 
they question discursive constructions of nomadism as the positive alternative to immobility and stasis.

Interviews for this research were completed in the months leading up to the Brexit referendum of 23 June 2016, hence still at a time when freedom of movement was a taken-forgranted right. Research enacted and published since then has shown how Brexit has destroyed this "taken-for-grantedness" and thrown the future plans of many young EU migrants in the UK into complete disarray. Brexit thus appears as an obvious rupture in Britain's relationship with the EU, as well as a personal rupture in the lives of young Southern and other Europeans living in this country who feel betrayed, angry and, typically, that they are no longer "welcome" (Lulle et al. 2018; Mazzilli and King 2018). Policies to reassure the rights of existing migrants to extend their stay, and of new migrants to arrive, have been painfully slow to emerge in the tortuous negotiations over the "type" of Brexit that will eventually be agreed.

\section{NOTE}

\footnotetext{
${ }^{1}$ Emigration rates are considerably higher if we add up the non-nationals, especially in Spain where two-thirds of the emigration outflow comprise foreign nationals.
}

\section{REFERENCES}

Bartolini, L., R. Gropas, and A. Triandafyllidou

2017

"Drivers of highly skilled mobility from Southern Europe: escaping the crisis and emancipating oneself", Journal of Ethnic and Migration Studies, 43(4): 652-673.

Bauman, Z.

2000

Liquid Modernity. Polity, Cambridge.

Bauman, Z.

2005. Liquid Life. Polity Press, Cambridge.

Beaverstock, J.V. and Hall, S.” 
Bermudez, A., and E. Brey

2017

"Is Spain becoming a country of emigration", in J.-M. Lafleur, \& M. Stanek (Eds.), South-North Migration of EU Citizens in Times of Crisis. Springer Open: 83-98.

Bygnes, S., and M.E. Erdal

2017

"Liquid migration, grounded lives: considerations about future mobility and settlement among Polish and Spanish migrants in Norway", Journal of Ethnic and Migration Studies, 43(1): $102-118$

Carling, J.

2002

"Migration in the age of involuntary immobility: theoretical reflections and Cape Verdean experiences." Journal of Ethnic and Migration Studies, 28 (1): 5-42.

Cresswell, T

2006

On the Move: Mobility in the Modern Western World. Routledge, London.

Conradson, D., and A. Latham

2005

"Friendships, networks and transnationality in a world city: Antipodean transmigrants in London". Journal of Ethnic and Migration Studies, 31(2): 287-305.

Conti, F.

2012 Leaving or Staying - An Analysis of Italian Graduates Migratory Patterns. Brighton: University of Sussex, DPhil thesis in Sociology.

D’Angelo, A., and E. Kofman

2017 "UK: large-scale European migration and the challenge to EU free movement", in J.-M. Lafleur, \& M. Stanek (Eds.), South-North Migration of EU Citizens in Times of Crisis. Springer Open: 175-191

Diaz-Hernandez, R., and M. Parreno-Castellano

"The recent international emigration of young Spaniards. The emigrants narrative versus the official and media perception”, in B. Glorius, and J. Domínguez-Mujica (Eds.), 
European Mobility in Times of Crisis. The New Context of European South-North

Migration. Transcript Verlag, Bielefeld: 245-265

Düvell, F., and D. Vogel,

2006

"Polish migrants: tensions between sociological typologies and state categories", in A.

Triandafyllidou (Ed.) Contemporary Polish Migration in Europe. Complex Patterns of

Movement and Settlement. Edwin Mellen Press, Lewiston, NY: 267-289.

European Commission

2010

Geographical and labour market Mobility. Special Eurobarometer 337

(http://ec.europa.eu/commfrontoffice/publicopinion/archives/ebs/ebs_337_en.pdf

accessed on $08 / 25 / 2018$ )

Engbersen, G.

2012

"Migration transitions in an era of liquid migration: reflections on Fassmann and

Reeger”, in M. Okólski, (Ed.) Europe, Continent of Immigrants: Trends, Structures and

Policy Implications. Amsterdam University Press, Amsterdam: 91-105.

Engbersen, G., E. Snel, and J. De Boom

2010 “A van full of Poles: liquid migration in Eastern and Central European countries”, in R. Black, G.B.M. Engbersen, M. Okólski et al. (Eds), A Continent Moving West? EU Enlargement and Labour Migration from Central and Eastern Europe. Amsterdam University Press, Amsterdam: 115-140.

Faist, T.

2013

“The mobility turn: a new paradigm for the social sciences?", Ethnic and Racial Studies, 36(11): 1637-1646

Favell, A.

2008

Eurostars and Eurocities: Free Movement and Mobility in an Integrating Europe.

Blackwell, Oxford.

Favell, A. 
2006. "London as Eurocity: French freemovers in the economic capital of Europe"”. In The

Human Face of Global Mobility: International Highly Skilled Migration in Europe,

North America, and the Asia-Pacific, Edited by: Smith, M.P. and Favell, A. 247-

74. Transaction, New Brunswick, NJ.

Friberg, J. H.

2012

"The stages of migration. From going abroad to settling down: Post-accession Polish migrant workers in Norway", Journal of Ethnic and Migration Studies, 38(10): 15891605.

Jordan, B., and F. Düvell

2003 Migration: The Boundaries of Equality and Justice. Polity Press, Cambridge.

King, R.

2002

“Towards a new map of European migration", International Journal of Population Geography, 8(2): 89-106.

King, R.

2015

“Migration and Southern Europe: a center-periphery dynamic?" in M. Baumeister and R. Sala (Eds.), Southern Europe? Italy, Spain, Portugal, and Greece from the 1950s until the Present Day. Campus Verlag, Frankfurt: 139-169.

King, R.

2018 “Theorising new European youth mobilities", Population, Space and Place, 24(1): e2117.

Klekowski von Koppenfels, A.K., and J. Höhne

2017 "Gastarbeiter migration revisited: consolidating Germany’s position as an immigration country again? Data, evidence and public responses”, in J.-M. Lafleur, \& M. Stanek (Eds.), South-North Migration of EU Citizens in Times of Crisis. Springer Open: 149174.

Labrianidis L., and M. Pratsinakis

2016 "Greece's new emigration at times of crisis", GreeSE: Hellenic Observatory Papers on Greece and Southeast Europe, 99, Hellenic Observatory, LSE. 
Labrianidis, L., and M. Pratsinakis

2017

“Crisis brain drain: short-term pain/long term gain?”, in D. Tziovas (Ed.) Greece in

Crisis: The Cultural Politics of Austerity, I.B. Tauris, London: 87-106

Levitt, P. and 'N. Glick Schiller'.

2004 "Conceptualizing simultaneity: A transnational social field perspective on society." International Migration Review, 38: 1002-1039.

Lulle, A., L. Morosanu and R. King

2018. "And then came Brexit: Experiences and future plans of young EU migrants in the London region. Population, Space and Place, 24(1): e2122.

Mavrodi, G., and M. Moutselos

2017 "Immobility in times of crisis? The case of Greece", in J.-M. Lafleur, \& M. Stanek (Eds.), South-North Migration of EU Citizens in Times of Crisis. Springer Open: 33-48.

Mazzilli, R. and King, R.

2018

“'What have I done to deserve this?' Young Italian migrants in Britain narrate their reaction to Brexit and plans for the future", Rivista Geografica Italiana, 125(4): 507-523.

Pratsinakis, M.

2019a Pratsinakis, M. 2019a "Family-related migration and the crisis-driven outflow from Greece.” In J. A. Panagiotopoulou, L. Rosen, C. Kirsch, et al. (Eds.): ‘New’ Migration of Families from Greece to Europe and Canada: A 'New' Challenge for Education? Springer VS, Wiesbaden: in press.

Pratsinakis, M. $2019 b$

Social and discursive constraints and the decision to leave: emigration from Greece at times of crisis (SEESOX Diaspora Working Paper Series No. 7). SEESOX, Oxford.

Pratsinakis, M., P. Hatziprokopiou, D. Grammatikas, et al.

2017

"Crisis and the resurgence of emigration from Greece: trends, representations, and the multiplicity of migrant trajectories” in B. Glorius, and J. Domínguez-Mujica (Eds.), 
European Mobility in Times of Crisis. The New Context of European South-North Migration. Transcript Verlag, Bielefeld: 75-104.

Recchi, E.

Mobile Europe: Theory and Practice of Free Movement in the EU. Palgrave Macmillan, Basingstoke.

Sala, A.L.

2019

"“You're not getting rid of us'. Performing acts of citizenship in times of emigration", Citizenship Studies, 23(2): 97-114

Santacreu, O., E. Baldoni and M. C. Albert

2009

'Deciding to move: migration projects in an integrating Europe', in E. Recchi and A. Favell (Eds), Pioneers of European Integration: Citizenship and Mobility in the EU. Edward Elgar, Cheltenham: 52-71.

Stark, O., and D. E. Bloom

1985

"The new economics of labor migration." American Economic Review, 75(2): 173-178.

Tiffin, A.

2013

"European productivity, innovation and competitiveness: The case of Italy", International Monetary Fund Working Paper, 14/79.

Tintori, G., and V. Romei

2017

"Emigration from Italy after the crisis: The shortcomings of the brain drain narrative". in J.-M. Lafleur, \& M. Stanek (Eds.), South-North Migration of EU Citizens in Times of Crisis. Springer Open: 49-64.

Urry, J

2007

Mobilities. Polity, Cambridge. 


\section{Figure 1}

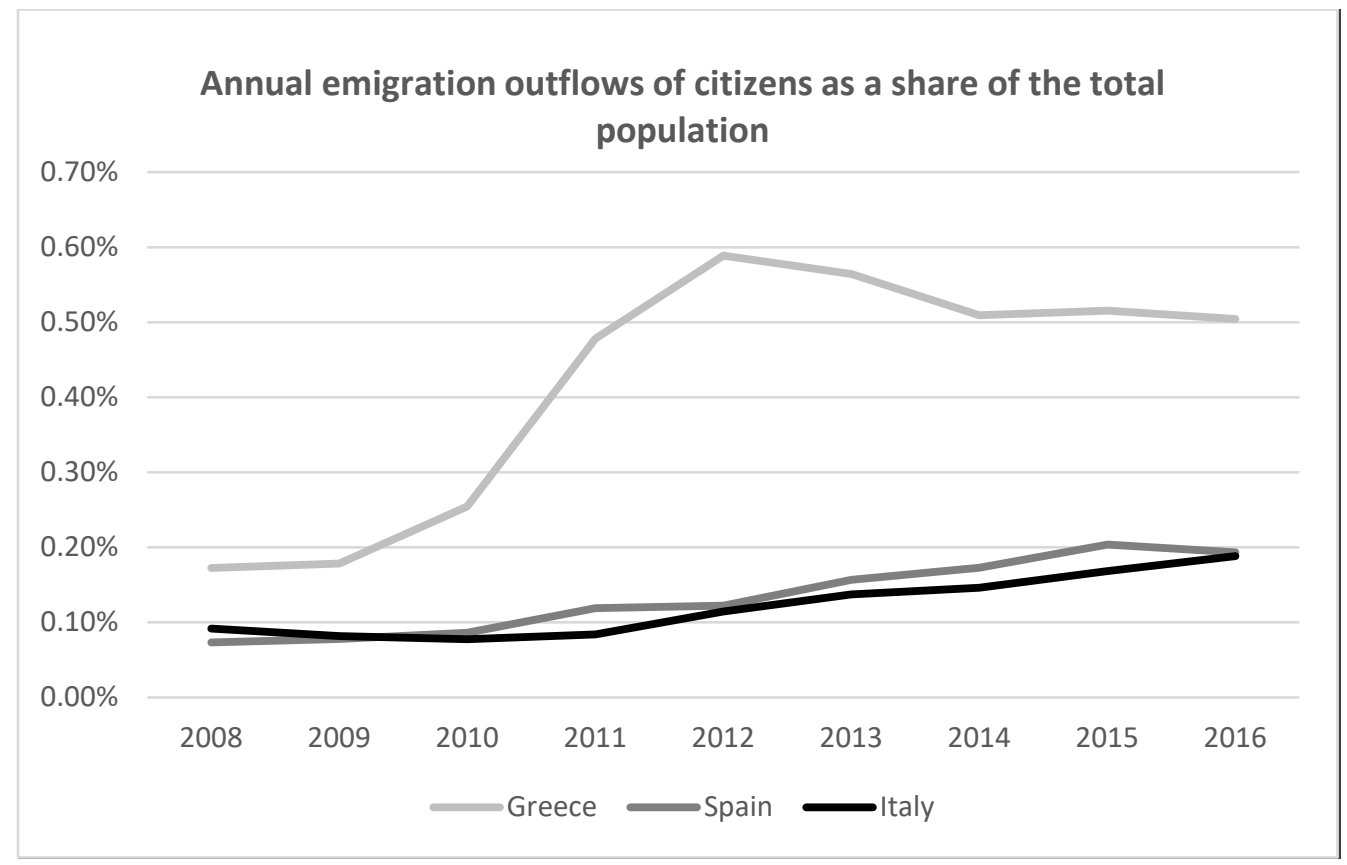

Source: Eurostat 
Figure 2

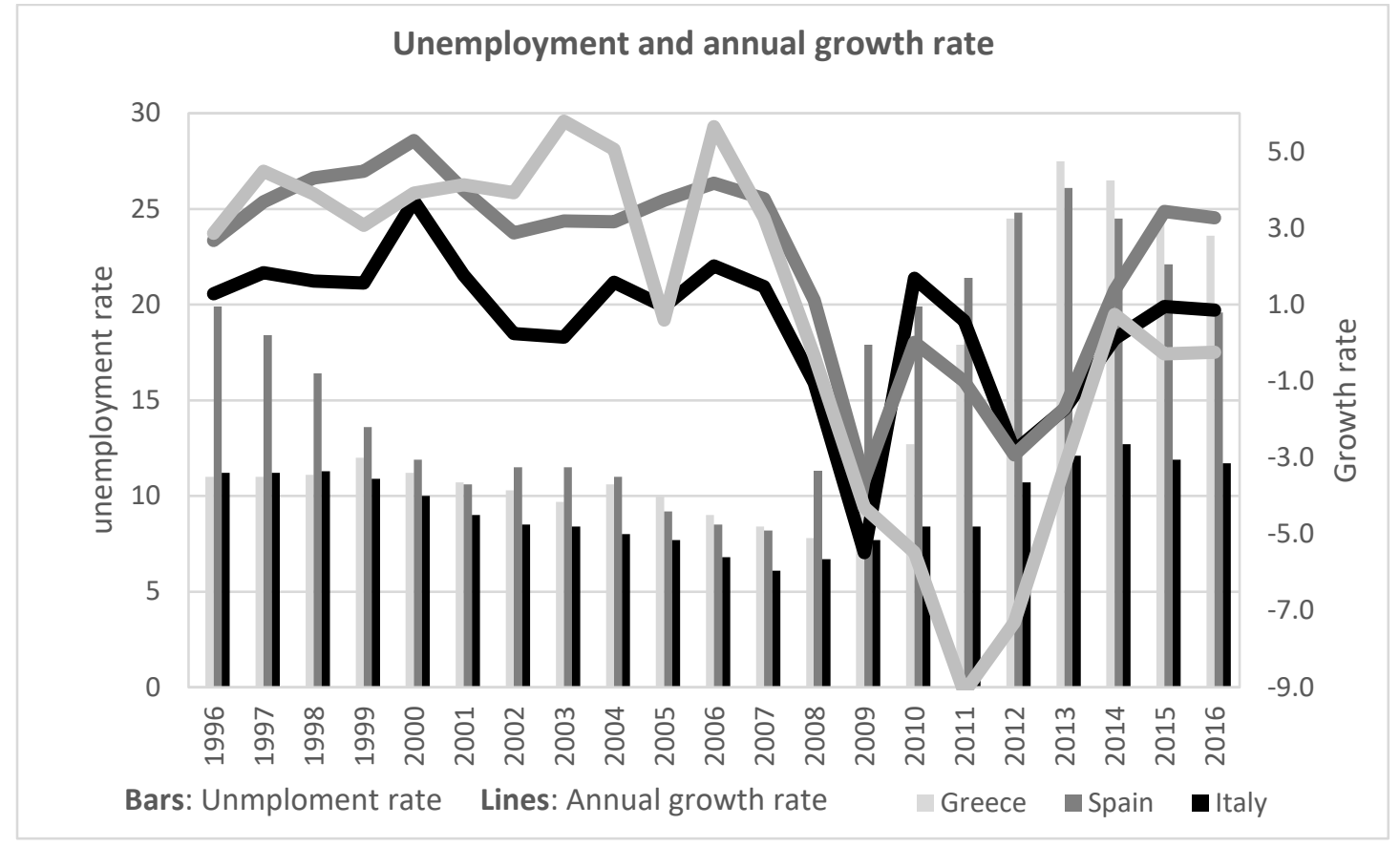

Sources: Eurostat, World Bank 
Figure 3

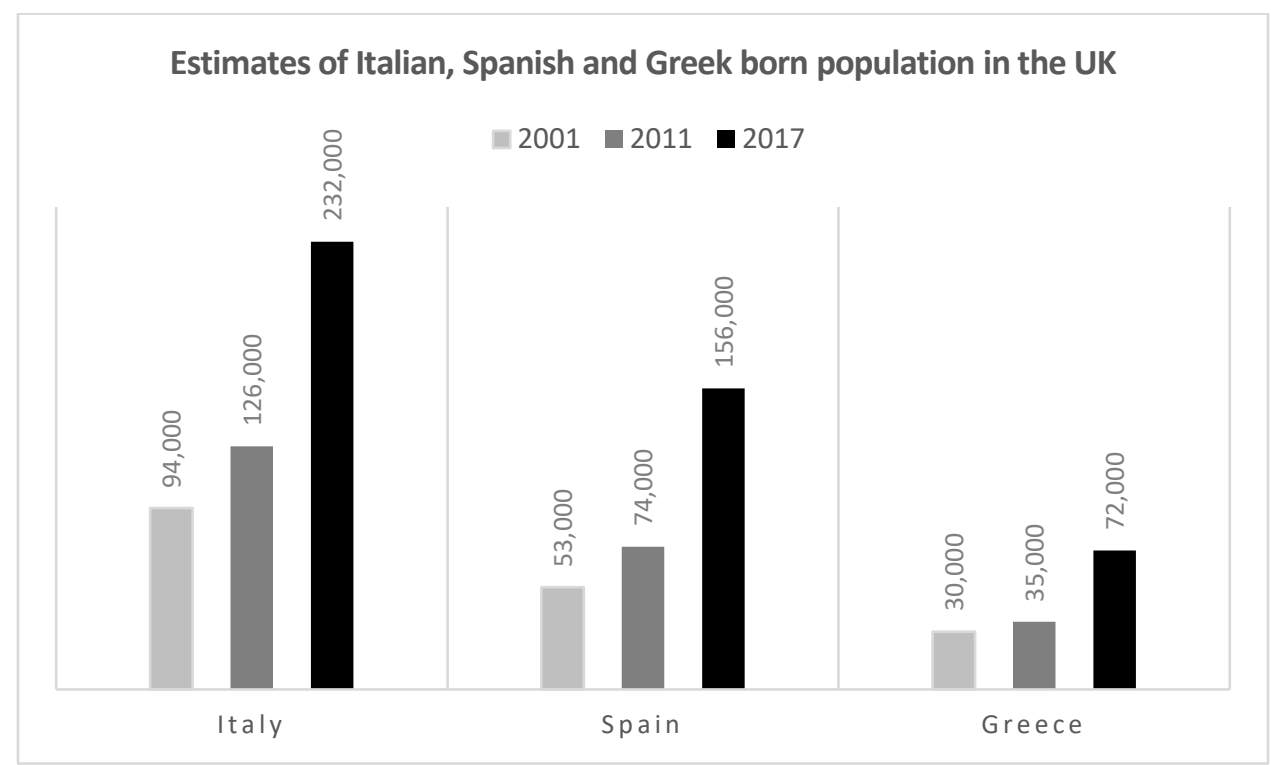

Source: Office for National Statistics, Annual Population Survey 